\title{
Evaluation of Hydrologic Modelling Using Satellite Product, and MMR Rainfall in East Java, Indonesia
}

\author{
Entin Hidayah ${ }^{1 *}$, Wiwik Yunarni Widiarti ${ }^{1}$, Paksitya Purnama Putra ${ }^{1}$, \\ Anggraeni Ayu Dewantie ${ }^{1}$, Muhammad Zulvi Alhamda ${ }^{1}$, Hanna Prastika ${ }^{1}$ \\ 1 Departement of Civil Engineering, University of Jember, Jalan Kalimantan No 37, 68121, Jember, Jawa Timur, \\ Indonesia \\ * Corresponding author's e-mail: entin.teknik@unej.ac.id
}

\begin{abstract}
In Indonesia, ground-based rainfall monitoring is uneven and sometimes lacks continuity especially in small watersheds, which makes hydrological modeling difficult. This paper aims to the performance evaluation of the HBV Light model from the manual measurement of rainfall (MMR), Global Precipitation Measurement (GPM3IMERGDF), and Tropical Rainfall Measuring Mission (TRMM-3B42) as input for the hydrological model. The Hydrologiska Byrans Vattenbalansavdelning (HBV) Light hydrological model is applied to three small watersheds, namely Sampean Baru, Bedadung, and Mayang. The model's performance evaluation is assessed based on the correlation between the average rainfall data for the satellite product area and the MMR product, the stationarity of the rainfall and discharge data, and the model accuracy. The model simulation results show that the MMR rainfall in all watersheds provides a better discharge response than the other two products. Meanwhile, the simulation model of the GPM-3IMERGDF satellite product is slightly better than TRMM-3B42. The stationarity test of rainfall and discharge data needs to be enforced before modeling.
\end{abstract}

Keywords: HBV light modeling, MMR; TRMM-3B42, GPM-3IMERGDF, stationarity data

\section{INTRODUCTION}

The imprecision of hydrological modeling depends on the availability of input rainfall data (Amorim et al., 2020; Gilewski \& Nawalany, 2018). Some of the obstacles that cause the inaccuracy of the hydrological model were inputs from the model that were not spatially and temporally appropriate (Huang et al., 2018). Observational rain gauges provide the most accurate rainfall measurements (Zhao et al., 2017), but the network of observation rain gauges was often not evenly distributed over a given area of climatic, economic, and other conditions. Spatial scarcity of rain gauge networks or none at all, especially upstream due to the difficulty of reaching them, poses a challenge to the accuracy of hydrological models Behrangi et al., 2011; Bitew \& Gebremichael, 2011; Koutsouris et al., 2016). The availabhility of freely available satellite-based rainfall products with high spatial and temporal resolution can solve the challenge or even replace the measurement of rain gauges (Fujihara et al., 2014; Koutsouris et al., 2016; Thiemig et al., 2013).

Several satellite rainfall data products have been developed to estimate regional rainfall using remote sensing technology. The National Aeronautics and Space Administration (NASA) created several rainfall data products with various temporal and spatial resolutions that are well known in the tropics (Huffman et al., 2007). Among the rainfall products from NASA are the Tropical Rainfall Measuring Mission (TRMM3B42) and Global Precipitation Measurement (GPM-3IMERGDF) which have continued their success. These two products were sufficient to be implemented in humid watersheds in China (Zhang et al., 2019). TRMM-3B42 itself has been tested on 3 different rainfall patterns in Indonesia, namely the equator, monsoon, and local with 
good results (Mamenun et al., 2014). In Selangor, Malaysia, the estimated TRMM-3B42 rainfall product correlates strongly with field rainfall data and can lower the rainfall threshold for landslide events (Tajudin et al., 2020). While the estimation of GPM-3IMERGDF satellite production in the Tibetan plateau was better at altitudes from 3000 $\mathrm{m}$ to $4000 \mathrm{~m}$, the bias was relatively small (RB) 6.4\% (Alazzy et al., 2017). GPM-3IMERGDF has also been tested in several cities in Indonesia. Estimates of rainfall for GPM-3IMERGDF products in Surabaya (lowland areas) provide a good correlation for ten daily and monthly periods, but not good for daily periods (Azka et al., 2018). GPM-3IMERGDF estimation with artificial neural network for daily scale gives good results in Mayang watershed, East Java, Indonesia (Hidayati et al., 2020). Satellite rainfall helps replace field observation data, especially for areas without measuring stations and areas not covered by weather radar (Wang et al., 2016).

In addition to comparing with rainfall data from a rain gauge, the performance assessment of satellite rainfall products can also be evaluated in another way, namely by using a hydrological model to predict river flow (Lakew et al., 2020; Worqlul et al., 2015; Zhao et al., 2017). Comparison of the TRMM-3B42 and GPM-3IMERGDF performance has been evaluated for various hydrological models such as VIC, HEC-HMS, and SWAT, where GPM-3IMERGDF shows a better fit than TRMM-3B42 (Amorim et al., 2020; Gilewski \& Nawalany, 2018; Zhang et al., 2019). However, daily TRMM-3B42 products were incorporated into various hydrological models that provide simulation output responses according to actual river flow observations (Zhao et al., 2017). TRMM-3B42 products were very useful for hydrological simulations in high mountain catchment areas (Xuan et al., 2018). Several regions have successfully applied TRMM-3B42 and GPM-3IMERGDF satellite rainfall products as inputs for hydrological modeling of mountainous areas. Complex hydrological modeling does not always give better results (Booij, 2003; Linde et al., 2007). However, the selection of an appropriate model was also important to produce an accurate hydrological model response.

One of the hydrological models is the HBV Light model which has shown its performance. The HBV (Hydrologiska Byrans Vattenbalansavdelning) model was a rainfall-runoff model that includes a numerical concept of hydrological processes at the watershed scale (Bergström, 1976, 1992). These models have been developed, including HBV-ETH (Braun \& Renner, 1990). HBV-96 (Lindström et al., 1997), and HBV-Light (Seibert, 2005). Evaluation of the calibration results and validation of the HBV-Light model with the input of various satellite rainfall data and field observations have been carried out in several watersheds in the world from various aspects (Lakew et al., 2020; Poméon et al., 2017). The evaluated aspects of the model include the structure and parameters of the model with the effect of temporal variability. The result was that the deviation from the simulation model was not affected by the structure of the model (Abebe et al., 2010; Linde et al., 2007). Some researchers say that the deviation of the model output was influenced by temporal variability (Abebe et al., 2010; Linde et al., 2007; Osuch et al., 2015; Rusli et al., 2015). Simulations on model calibration show good performance and tend to decrease in the validation phase (Mendez \& Calvo-Valverde, 2016; Osuch et al., 2015; Rusli et al., 2015). The possible decline in validation performance was influenced by the data period for validation being too short and the presence of missing discharge data (Poméon et al., 2017; Rusli et al., 2015). In addition, modeling by separating rainfall input for the wet and dry seasons has not provided a model certainty (Alhamda et al., 2020; Linde et al., 2007).

Related to the evaluation results above, data variability is a major problem in model uncertainty because some hydrological time series data have weak stationary (Rutkowska \& Ptak, 2012). So, the level of stationary data needs to be questioned before doing the modeling. Therefore, this study was conducted by examining the stationarity of the rainfall and discharge time series data on the response of the HBV Light model which had never been done by previous researchers. In addition, the performance of the model was measured by comparing the input of field rainfall MMR and 2 satellite products (TRMM-3B42 and GPM-3IMERGDF) as well as the output of the modeling with the observed discharge. This modeling was applied in small watersheds in East Java, namely Sampean Baru, Bedadung, and Mayang. This third watershed is the main air source for irrigation activities, so it is necessary to investigate the availability of water. The watershed characteristics in the three watersheds have spatial and temporal variability (Indarto et al., 2014) the discharge is rangked from high to low flow. 
Results from TLM are then imported to EXCEL for further analysis. Furthermore, GIS software package (Quantum GIS. This area upstream was a plateau with a complex topography and no rain gauge was available. This study effort to understand the diversity through hydrological modeling to determine the effect of each component.

\section{MATERIALS AND METHODS}

\section{Study area description}

The location of this research was in three small watersheds, including Sampean Baru, Bedadung, and Mayang which are located in Bondowoso and Jember Regencies which have different topographical aspects, namely the Java Sea and two other watersheds that drain parallel to the Samodera Indonesian. The source of this river's water comes from springs on Mount Argopuro and Mount Raung. The area of the Sampean Baru, Bedadung, and Mayang watersheds are approximately $703 \mathrm{~km}^{2}, 648 \mathrm{~km}^{2}$, and $578 \mathrm{~km}^{2}$, respectively, taken from the Digital Elevation Model (DEM) with a resolution of 30x30m. The number of meteorological stations and the drainage patterns of the Sampean Baru (22), Bedadung (14), and Mayang (11) watersheds is depicted in Figure 1 . The density of the rain station network per $\mathrm{km}^{2}$ from densest to sparse for the Sampean Baru, Bedadung, and Mayang watersheds overall respectively were $31.96,46.46$, and 52.6. The Sampean Baru, Bedadung, and Mayang watersheds have a complex topography with significant elevation variations between 1890 and 3530 and 990 to $2725 \mathrm{~m}$. The slope of the watershed varies from zero to $140 \%$, with an average slope of $12 \%$ for the Mayang watershed and 14\% for the Bedadung watershed. About $50 \%$ of the watershed has a slope of less than $8 \%$. The Sampean Baru, Bedadung and Mayang watersheds have an average annual rainfall of 1860, 1550, and $1641 \mathrm{~mm}$, respectively. The primary rainy season is from June to September and accounts for $70 \%$ to $90 \%$ of the annual rainfall.

\section{Research stages}

This research was divided into three stages, namely data collecting, data processing, and hydrological modeling. Data requirements include rain, discharge, and climatological data. The data processing includes the calculation of the regional average rainfall and potential evapotranspiration. The last stage was HBV Light hydrological modeling. The stages in detail can be seen in each process in Figure 2.

\section{Manual measurement of rainfall MMR data}

Temporal rainfall data used was daily rainfall. Daily rainfall data was obtained from rain gauges located in 3 watersheds with the number of rain

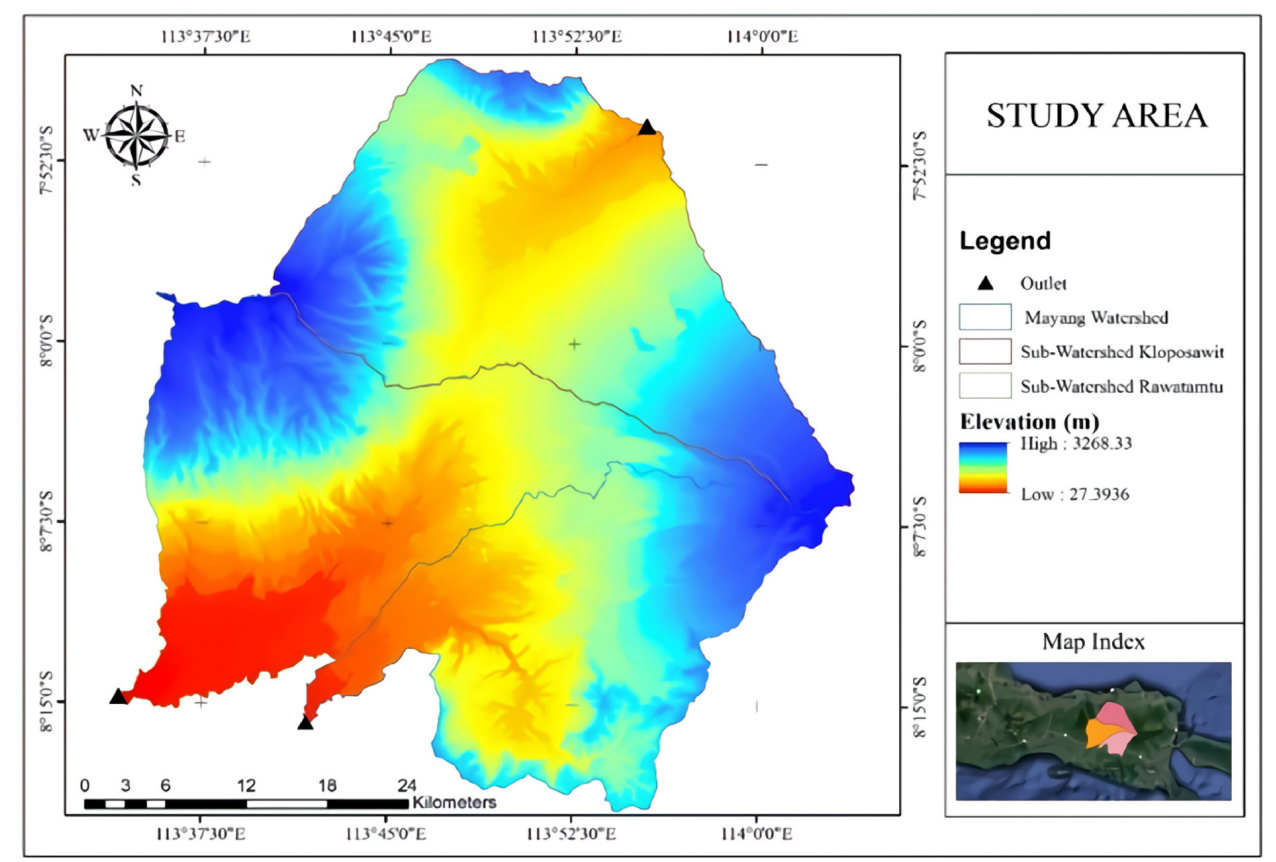

Figure 1. Maps of the study area 


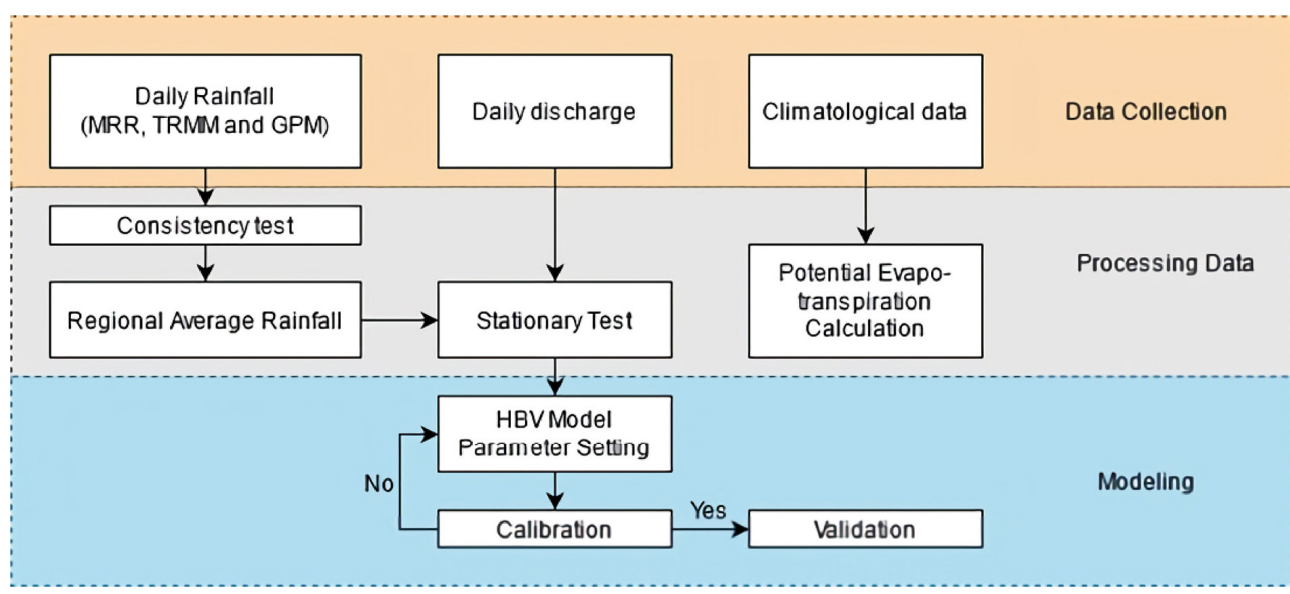

Figure 2. Step of methodology

gauges for Bedadung, Mayang, and Sampean Baru respectively 14, 11, and 22 gauges.

Rain gauge data from 2008 to 2017 were collected from the East Java Provincial Public Works Agency for several stations. Estimated area rainfall was interpolated using the Thiessen Polygon method (Gu et al., 2010; Rusli et al., 2015). In the method, each rain gauge has a weight based on the area of influence on the watershed. Field observation rainfall data used at each station in each watershed was consistent rain data where the quality of the data has been tested using the multiple mass curve method.

\section{Satellite rainfall products data}

TRMM-3B42 and GPM-3IMERGDF. Rainfall forecasts were available for the period 1998 to the present. The algorithm integrates rainfall forecasts from multiple satellites and various sensors. The TRMM-3B42 has a wide range of $50^{\circ} \mathrm{S} \sim 50^{\circ} \mathrm{N}$, and high temporal $(3 \mathrm{~h})$ and spatial $\left(0.25^{\circ} \times 0.25^{\circ}\right)$ resolution (Gu et al., 2010). Meanwhile, GPM-3IMERGDF as a continuation of TRMM-3B42 has a better spatial resolution $\left(0.1^{\circ} \times 0.1^{\circ}\right)$. The rainfall data for TRMM-3B42 provides more accurate predictions than TRMM3B42 and can carry out further research on this data (Liu, 2014). Both data can be downloaded from (https://disc.gsfc.nasa.gov). Furthermore, satellite rainfall data can be extracted from the file using the Panoply application. The estimated rainfall for this satellite product area uses the Thiessen Polygon method by assuming the coordinates of the grid data as the satellite location of the rain gauges.

\section{Evapotranspiration data}

Inputs for HBV Light model include the longterm monthly evaporation potential estimated with the Penman combination. Potential evaporation data were not measured in 3 watersheds, so potential evapotranspiration was estimated from the reanalysis of the Climate Forecasting System Reanalysis (Poméon et al., 2017). The data needed to calculate evapotranspiration includes data on average temperature $\left({ }^{\circ} \mathrm{C}\right)$, relative humidity (\%), daily sun exposure (\%), and wind speed $(\mathrm{m} / \mathrm{s})$. Climatological data were gained from Umbulsari Station, UPT SDA, East Java Province.

\section{Discharge data}

Observational discharge data were used as HBV Light input. Daily discharge data was taken from the measurement results of each watershed outlet. The measurement locations for the outlets of the Sampean Baru, Bedadung, and Mayang watersheds were the Klapa Sawit station, the Rawatamtu DAM station, and the Talang DAM station. Daily discharge data were taken from the Public Works Department of East Java Province. The use of discharge data with a period of 20112016 for the Sampean Baru watershed and 2008 to 2017 for Bedadung and Mayang.

\section{Stationary test for hydrological time series data}

The stationarity examination of the hydrological time series data uses unit root tests, namely Augmented Dickey-Fuller (ADF) which was tested using Gretl software. The ADF test was a statistical test on the estimated coefficients in the 
regression to determine the presence of the unit root (Cryer \& Chan, 2008). The presence of a unit root indicates that the data was not stationary (Said \& Dickey, 1984). This test was commonly used for testing the stationarity of hydrological data (Khalili et al., 2013; Rutkowska \& Ptak, 2012).

The ADF has been used to test the stationarity of the time series of rainfall and discharge data uses with constant models. This was intended to test the stationary data against the average. The hypothesis of the ADF test if -1 was equal to zero then it has a unit root or was not stationary, otherwise if -1 was not equal to zero then the data was said to be stationary. The ADF statistical formula is found in equation (1).

$$
Y_{t}=(\alpha-1) Y_{t-1}+\varepsilon_{t}
$$

where: $Y_{t}-$ the time series data,

$\varepsilon_{t}-$ error while -1 was the coefficient of $Y_{t-1}$.

The test was done by comparing the p-value with the real level. The data was said to be stationary if the p-value was less than the $5 \%$ significance level. ADF test statistics were shown in equation (2) and (3) (Wei, 2006).

where:

$$
\mathrm{ADF}=\frac{\alpha-1}{s_{\alpha}}
$$

$$
\begin{gathered}
S_{\alpha}=\left(\sigma_{\alpha^{2}}\left(\sum_{t=1}^{n} Z_{t-1}^{2}\right)^{-1}\right)^{1 / 2} \text { and } \\
\sigma_{\alpha}^{2}=\sum_{t=1}^{n} \frac{\left(Z_{t}-\alpha Z_{t-1}\right)^{2}}{(n-1)}
\end{gathered}
$$

where: $S_{\alpha}-$ Standard error,

$\alpha$ - estimator parameter,

$n$ - the number of observations.

\section{Description of HBV light hydrology}

The HBV Light model (Hydrologiska Byråns Vattenbalansavdelning) (Lindström et al., 1997) was a conceptual hydrology model for simulating daily runoff of catchment areas. This model has the advantage that it requires little input data (Bergström, 1992; Rusli et al., 2015), the structure of the model was simple and the parameters were limited when compared to other models (Abebe et al., 2010).

This model simulates using daily rainfall, temperature, long-term average monthly evaporation potential, and observed runoff data for calibration (Seibert, 2005). The HBV Light structural model using the water balance concept was shown in Equation (4):

$$
P-E-Q=\frac{d}{d t}(S M+U Z+L Z+L)
$$

where: $P$ - rainfall (mm/day),

$E$ - evapotranspiration (mm/day),

$Q-$ runoff (mm/day),

$S M$ - soil moisture,

$U Z$ - topsoil zone (mm),

$L Z$ - subsoil zone (mm),

$L-$ the volume of the lake $(\mathrm{mm})$.

The structure of this model consists of four main routines including precipitation, soil, routing, and response consisting of linear and nonlinear reservoirs. (Seibert \& Vis, 2012). The first routine, snow storage was neglected for this study using only rainfall. Excessive rainfall stores shallow soil layers resulting in infiltration which was described as an upper non-linear reservoir. The reservoir non-linearity was controlled by the Alpha $(\alpha)$ parameter. The second routine for calculating soil moisture was based on three parameters, Beta ( $\beta), F C$, and LP control the contribution to the response function of each millimeter of rainfall. FC was the maximum soil moisture storage. As soil moisture exceeds the potential evaporation limit (LP), water will evaporate at a potential rate. The third routine was the lower linear response routine (Interflow (Q1) controlled with parameter K1). K1 and K2 were the recession coefficient parameters for the upper and lower response parameters (baseflow routing coefficients). Finally, the triangular weight function of the base length, Maxbas, was used to route the three flow components. Both simulation models were calibrated manually, first by adjusting the volume of runoff followed by calibrating the shape of the hydrograph to measure rainfall and discharge data.

\section{Assessment of model performance}

The performance of the model was tested from two sides, namely the statistical test of rain and discharge data and the response of the hydrological modeling. The statistical test of rain data includes the correlation of the data and its stationary. While the discharge will also be tested for stationary. The correlation of satellite rainfall data was tested against field rainfall data (Worqlul et al., 2015). While the hydrological modeling was measured by the comparison between the simulation results and discharge observations. Statistical testing of the rainfall data needs to be carried out to determine the difference between the TRMM3B42 and GPM-3IMERGDF satellite products on the rain gauge data. The statistical tests used 
Table 1. Tests, functions, equations, and statistical metric units to measure performance

\begin{tabular}{|c|c|c|c|}
\hline Function & Performance & Equation & \\
\hline \multicolumn{4}{|c|}{ PBias (\%) } \\
\hline $\begin{array}{l}\text { PBIAS was used to measure the } \\
\text { suitability between the average value of } \\
\text { the measuring data and the observed } \\
\text { data as in eq (5) }\end{array}$ & $\begin{array}{l}\text { The optimal value of PBIAS was } 0.0 \text {, with a } \\
\text { low magnitude value indicating an accurate } \\
\text { model simulation. A positive value indicates } \\
\text { an underestimation model bias, and a } \\
\text { negative value indicates an overestimation } \\
\text { bias model [Gupta et al., 1999] }\end{array}$ & PBias $=\frac{\sum_{i=1}^{n}\left(O_{i}-P_{i}\right) *(100)}{\sum_{i=1}^{n} o_{i}}$ & (5) \\
\hline \multicolumn{4}{|c|}{ Coefficient correlation (NA) } \\
\hline $\begin{array}{l}\text { CC was used to assess the linearity of } \\
\text { the correlated data set. The formula of } \\
\text { CC was shown in eq (6) }\end{array}$ & $\begin{array}{l}\text { The correlation coefficient }(R) \text {, which ranges } \\
\text { from } 1 \text { to } 1 \text {, was an index of the degree of a } \\
\text { linear relationship between the observed and } \\
\text { simulated data. If } C C=0 \text {, there was no linear } \\
\text { relationship. If } C C=1 \text { or } 1 \text {, there was a } \\
\text { perfect positive or negative linear relationship } \\
\text { [Moriasi et al., 2007]. }\end{array}$ & $\mathrm{CC}=\frac{\sum_{i=1}^{n}\left(o_{i}-\bar{O}\right)\left(P_{i}-\bar{P}\right)}{\sqrt{\sum_{i=1}^{n}\left(o_{i}-\bar{O}\right)^{2}} \sqrt{\sum_{i=1}^{n}\left(P_{i}-\bar{P}\right)^{2}}}$ & (6) \\
\hline \multicolumn{4}{|c|}{ Nash-Sutcliffe efficiency (NA) } \\
\hline $\begin{array}{l}\text { NSE examines the degree of a linear } \\
\text { relationship between the observed and } \\
\text { simulated flows shown in eq (7) [Nash \& } \\
\text { Sutcliffe, 1970]. }\end{array}$ & $\begin{array}{l}\text { NSE ranges between and } 1.0 \text { ( } 1 \text { inclusive), } \\
\text { with NSE }=1 \text { as the optimal value. A value } \\
\text { between } 0.0 \text { and } 1.0 \text { was generally seen as } \\
\text { an acceptable level of performance. }\end{array}$ & $\mathrm{NSE}=1-\left(\frac{\sum(Q o b s-Q s i m)^{2}}{\sum(Q o b s-Q o b s)^{2}}\right)$ & \\
\hline
\end{tabular}

Note: $\bar{P}$ - the mean predicted rainfall; $\bar{O}$ - the average observed rainfall; $n$-number of samples; $P_{i}-$ prediction of rainfall or discharge; $\mathrm{Oi}$ - measured rainfall or metered discharge; Qobs - discharge observations; Qsim discharge simulation model.

include the percent relative bias (PBias) and the correlation coefficient $(\mathrm{CC})$ which are shown in equations (4) and (5) in Table 1. While the hydrological model response test uses percent bias (PBias), RSR, and Nash-Sutcliffe Efficiency (NSE). The formulas for each were shown in equations (4), and (6).

\section{RESULTS}

\section{Statistic test of rainfall and discharge data}

Area rainfall data in each watershed from 2 satellite products are compared to test the strength of their relationship with area rainfall on the rain gauge. Based on the calculation of rainfall in the Sampean Baru, Bedadung, and Mayang watersheds, it is obtained that the difference in the daily average value of the three rainfall product data (MMR, TRMM-3B42, and GPM-3IMERGDF). The average rainfall depth and standard deviation of all watersheds are presented in Figure 3. Based on the ranking of the average MMR rainfall from the lowest to the highest, respectively, the Sampean Baru watershed (5.3 $\mathrm{mm} /$ day), Bedadung watershed $(6.5 \mathrm{~mm} /$ day $)$ day, and Mayang watershed $(9.0 \mathrm{~mm} /$ day $)$. While the average rainfall height from the TRMM-3B42 and GPM-3IMERGDF satellite products has the same average pattern, respectively, from the lowest to the highest, namely the Bedadung Watershed $(5.9$ and $6.7 \mathrm{~mm} /$ day), Mayang Watershed (5.7 and $6.3 \mathrm{~mm} /$ day), and the Sampean watershed $(5.4$ and $6.1 \mathrm{~mm} /$ day). The results of the comparison of the standard deviation of the three watersheds for MMR products from the smallest to the largest are sequentially the same as the average rainfall depth, namely the Sampean Baru watershed $(8.3 \mathrm{~mm} /$ day), Bedadung watershed $(9.5 \mathrm{~mm} /$ day $)$ and Mayang watershed $(14.2 \mathrm{~mm} /$ day $)$. Meanwhile, the GPM-3IMERGDF satellite product has a smaller standard deviation than TRMM-3B42. If ranked from the watersheds that have a standard deviation of the TRMM-3B42 and GPM-3IMERGDF satellite products from the smallest to the largest, they are the Sampean Baru watershed (10.5 and $9.5 \mathrm{~mm} /$ day), Bedadung watershed (11.2 and 10.6 $\mathrm{mm} /$ day $)$ and Mayang watershed $(11.5 \mathrm{~mm} /$ day and $10.7 \mathrm{~mm} /$ day).

The results of the analysis based on the CC value between satellite data TRMM-3B42 and GPM-3IMERGDF to the observation data for the three watersheds have a positive linear relationship, but only the Sampean Baru watershed has a satisfactory correlation, while the other two watersheds are less than satisfactory. The higher resolution of GPM-3IMERGDF affects increasing the correlation value of TRMM 3B42. The improvement in the resolution of 


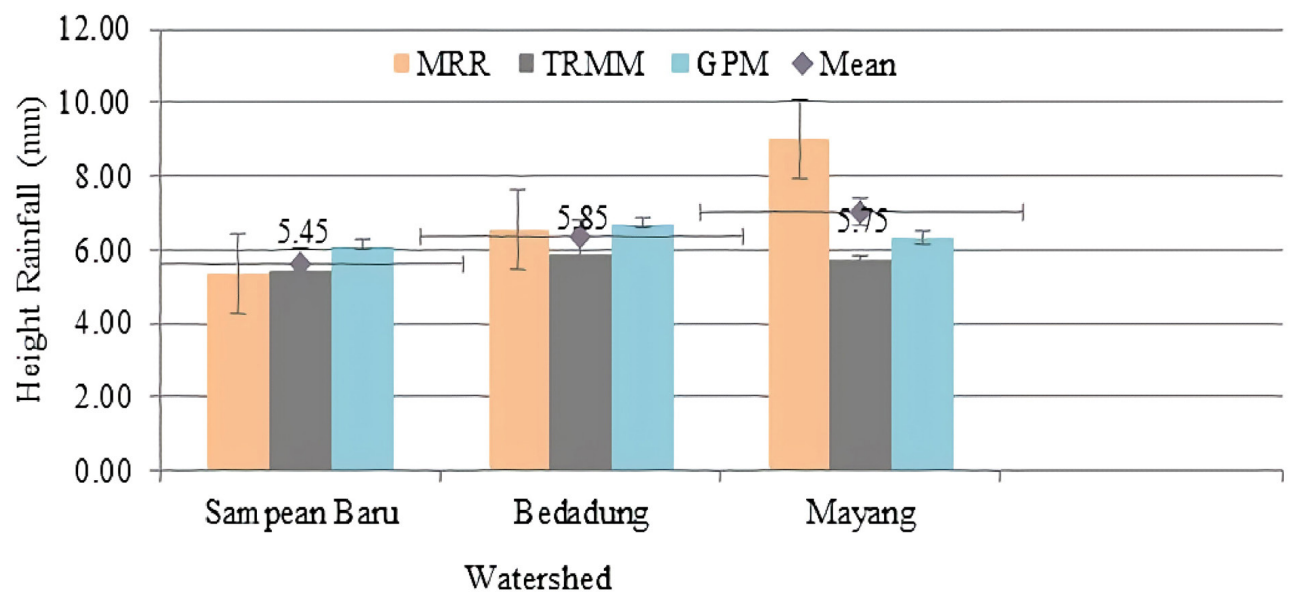

Figure 3. Average annual rainfall for all products from 3 watersheds, Sampean Baru (2011-2016); Bedadung and Mayang (2008-2017)

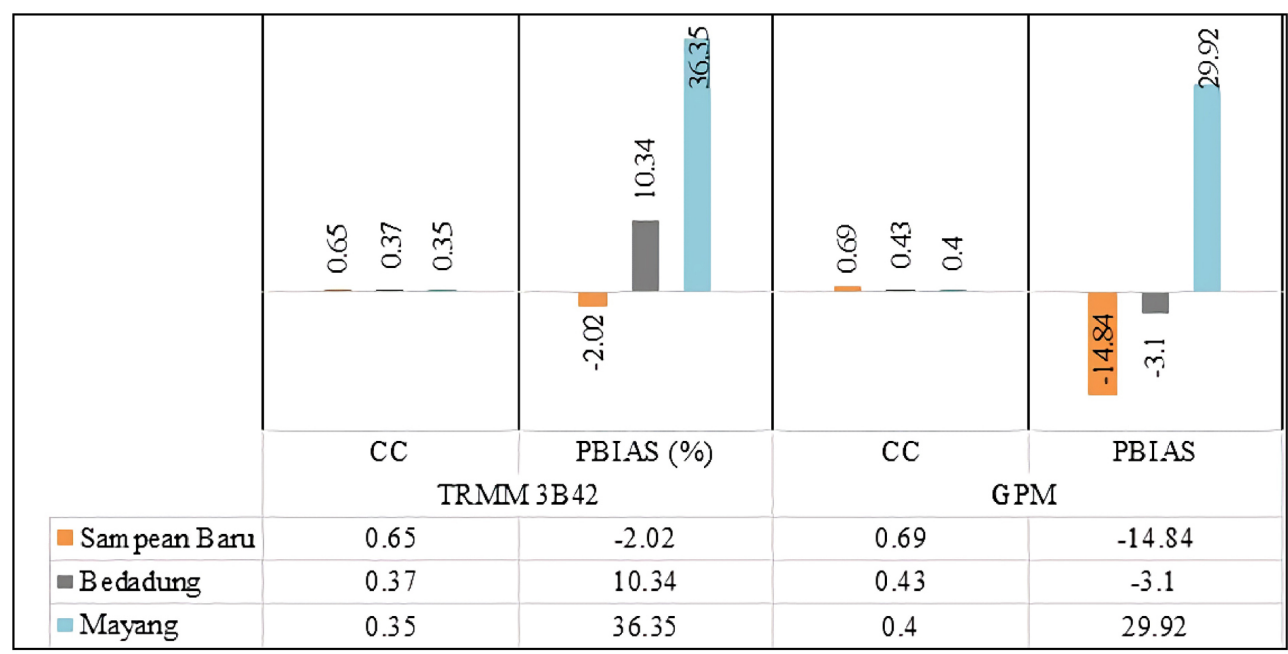

Figure 4. Statistical assessment between satellite and ground-based rainfall in 3 watersheds

$0.25^{\circ} \times 0.25^{\circ}$ to $0.1^{\circ} \times 0.1^{\circ}$ has an average correlation increase of $5 \%$.

It can be seen in Figure 4 that the TRMM3B42 satellite data product based on the PBIAS value in the Sampean Baru watershed has a negative value to the MMR rainfall data, but the Bedadung and Mayang watersheds have a positive value. Meanwhile, the PBIAS value of the GPM-3IMERGDF data product in the Bedadung and Sampean watersheds is also negative. In general, the Sampean Baru watershed has a better performance than the other two watersheds based on the correlation value.

Based on Table 2, all rainfall data from the three products in each watershed p-value nonseasonal and seasonal was less than the $5 \%$ significance level, so that all rainfall data for MMR and satellites TRMM-3B42 and GPM3IMERGDF are all stated to be stationary with respect to the average.

Based on Table 3, the results of the ADF test show that the discharge in the Sampean Baru

Table 2. Stationary test 2 satellite rainfall products and $1 \mathrm{MMR}$

\begin{tabular}{|c|c|c|c|c|c|c|}
\hline \multirow{2}{*}{ Watershed } & \multicolumn{3}{|c|}{ Asymptotic $p$-value ADF Non-seasonal } & \multicolumn{3}{c|}{ Asymptotic $p$-value ADF seasonal } \\
\cline { 2 - 7 } & MMR & TRMM-3B42 3B42 & $\begin{array}{c}\text { GPM-3IMERGDF - } \\
\text { 3IMERGDF }\end{array}$ & MMR & $\begin{array}{c}\text { TRMM-3B42 } \\
\text { 3B42 }\end{array}$ & $\begin{array}{c}\text { GPM-3IMERGDF- } \\
\text { 3IMERG }\end{array}$ \\
\hline $\begin{array}{c}\text { Sampean } \\
\text { Baru }\end{array}$ & 0.001373 & 0.0002889 & 0.002959 & 0.001438 & 0.0002926 & 0.001666 \\
\hline Bedadung & 0.0003195 & $4.01 \mathrm{E}-05$ & 0.0001 & 0.0003239 & $4.13 \mathrm{E}-05$ & 0.0001 \\
\hline Mayang & 0.0003738 & $5.91 \mathrm{E}-06$ & $4.59 \mathrm{E}-05$ & 0.0003304 & $6.10 \mathrm{E}-06$ & $4.68 \mathrm{E}-05$ \\
\hline
\end{tabular}




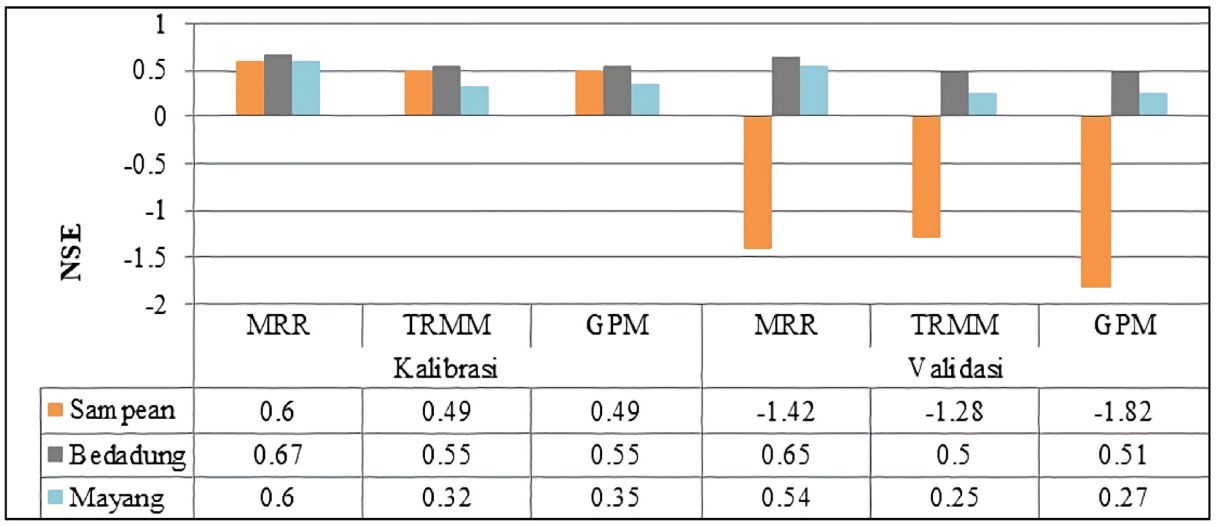

(a)

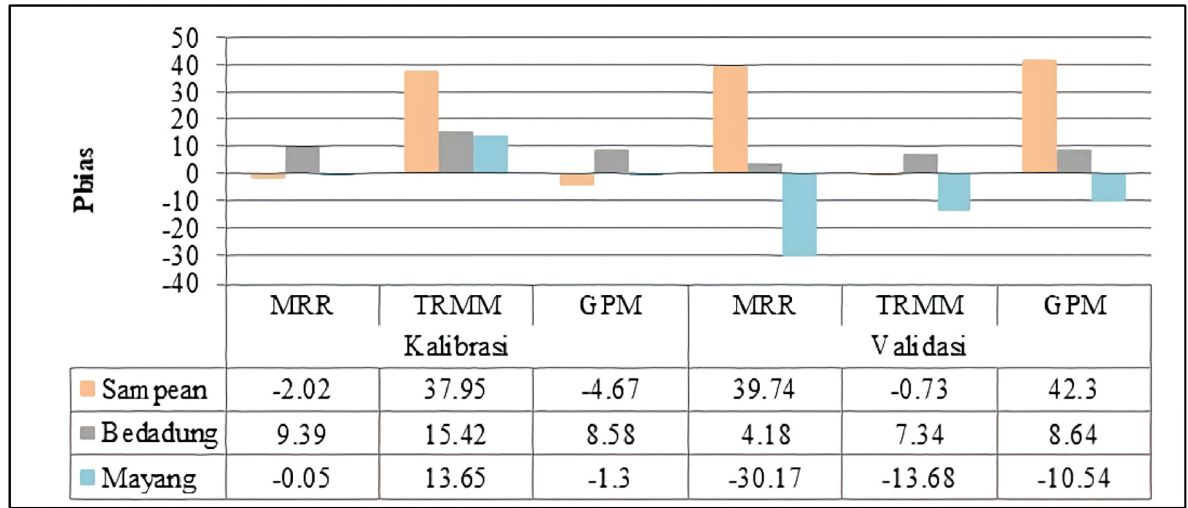

(b)

Figure 5. (a) NSE (b) Pbias calibration and validation model using 3 rainfall data products for the watershed: Sampean Baru, Bedadung, Mayang

Table 3. Stationary test of observation discharge data

\begin{tabular}{|c|c|}
\hline Watersheds & Asymptotic $p$-value ADF test \\
\hline Sampean Baru & 0.1631 \\
\hline Bedadung & $3.635 \mathrm{E}-006$ \\
\hline Mayang & $3.631 \mathrm{E}-006$ \\
\hline
\end{tabular}

watershed for the period 2011-2016 has a pvalue of more than the $5 \%$ real level so that the data is not stationary with respect to the average.
Meanwhile, Bedadung and Mayang watersheds have stationary data.

\section{HBV light model performance}

Parameters resulting from calibration of $\mathrm{HBV}$ Light modeling by comparing two different input data are shown in Table 4. These parameters values that represent the physical conditions of the

Table 4. Parameters and calibration results

\begin{tabular}{|c|c|c|c|c|c|c|c|c|c|}
\hline \multirow{2}{*}{$\begin{array}{c}\text { HBV } \\
\text { model } \\
\text { parameter }\end{array}$} & \multicolumn{3}{|c|}{ Sampean Baru Watershed } & \multicolumn{3}{c|}{ Bedadung Watershed } & \multicolumn{3}{c|}{ Mayang Watershed } \\
\cline { 2 - 11 } & MMR & TRMM-3B42 & GPM-3IMERGDF & MMR & TRMM-3B42 & GPM-3IMERGDF & MMR & TRMM-3B42 & GPM-3IMERGDF \\
\hline FC & 100 & 160.33 & 549 & 200 & 50 & 144 & 500 & 549 \\
\hline LP & 0.82 & 0.33 & 0.3 & 1 & 1 & 0.99 & 0.2 & 0.2 & 290 \\
\hline BETA & 4.08 & 1 & 4.9 & 1 & 1 & 1 & 3.2 & 4.7 & 0.1 \\
\hline Alpha & 0.79 & 0.53 & 0.79 & 0.77 & 0.24 & 0.391 & 0.7 & 0.36 & 0.16 \\
\hline K1 & 0.12 & 0.15 & 0.11 & 0.17 & 0.15 & 0.144 & 0.1 & 0.1 \\
\hline K2 & 0.002 & 0.002 & 0.0015 & 0.03 & 0.07 & 0.049 & 0.0001 & 5 E-05 & 2.33 \\
\hline MAXBAS & 1.555 & 1.46 & 1.4 & 1.65 & 1.1 & 1.52 & 1 & 1.7 & 2 E-07 \\
\hline Cet & $3 \mathrm{E}-08$ & 1.104 & 0 & 1 & 0.37 & 0.29 & 1 & 0.4 & 2 \\
\hline PART & 0.145 & 0.128 & 0.15 & 0.43 & 0.447 & 0.49 & 0.1 & 0.16 & 0.29 \\
\hline
\end{tabular}


watershed under study. The results of the evaluation of the HBV-Light model will be assessed based on the NSE value, Pbias contained, and the model pattern as seen in Figure 5. and 6.

The results of the ANOVA test of the HBV Light model parameters for all variations of rainfall data in all watersheds found that all parameters mutually influence the model response simultaneously because the p-value (1.9E-12\%) is less than the $5 \%$ significance level. The results of the Tukey multiple comparison tests show that the FC parameter has a different effect from the other parameters because the average difference between the FC parameter and the other parameters is greater than the significantly honest difference value. Furthermore, the results of the Tukey multiple comparison test between watersheds showed that the FC parameters are not different. However, if sorted by the average FC parameter, the Mayang watershed has the largest FC average value compared to the other two watersheds. This confirms that the HBV Light modeling in the Mayang watershed has the lowest performance compared to others.

Based on Figure 6, the trend of model simulation results in the calibration period for all rainfall products shows the same pattern according to the region. In the Sampean

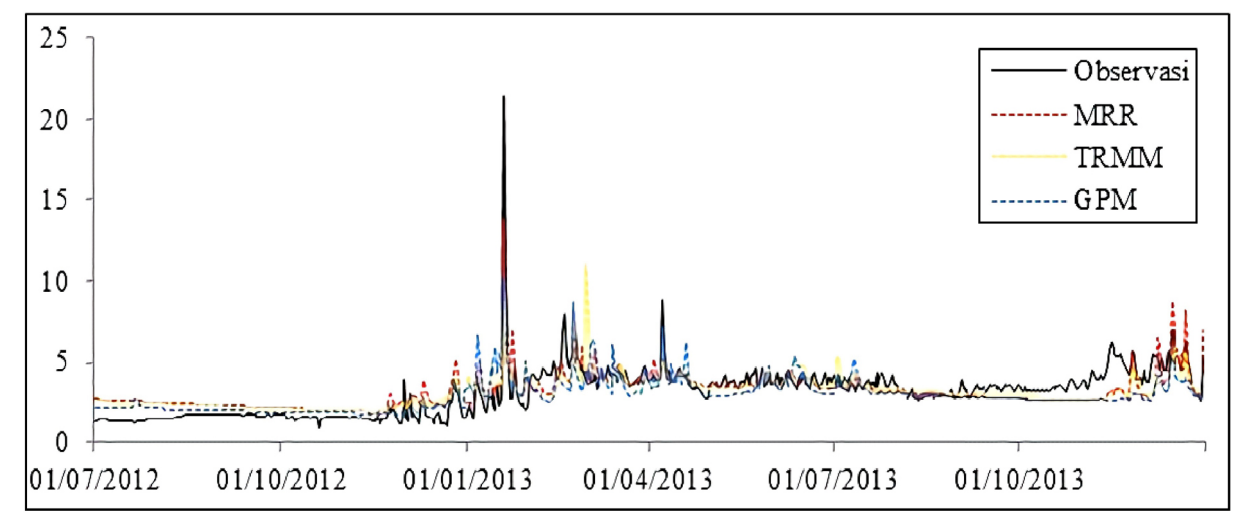

(a)

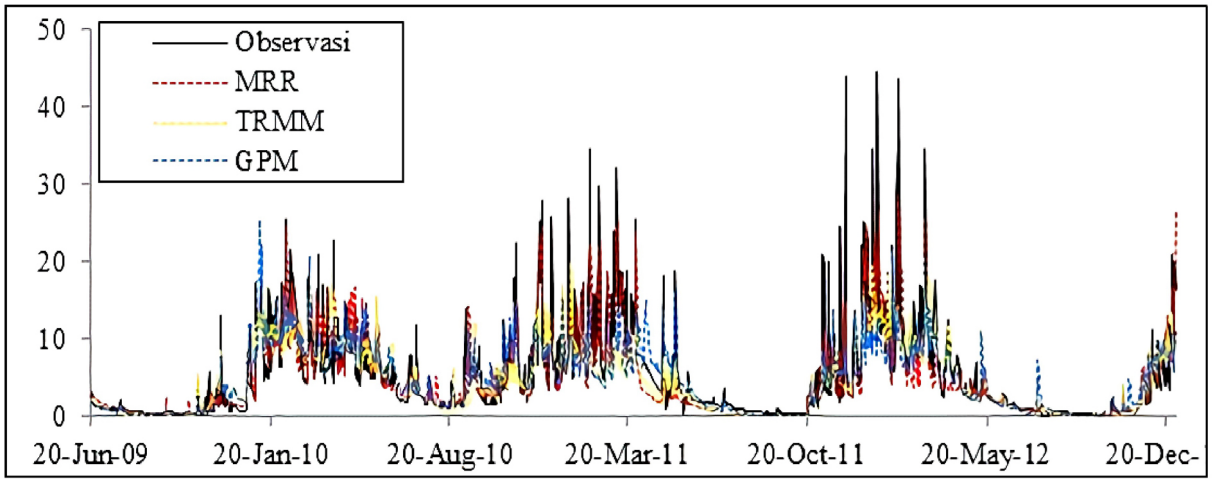

(b)

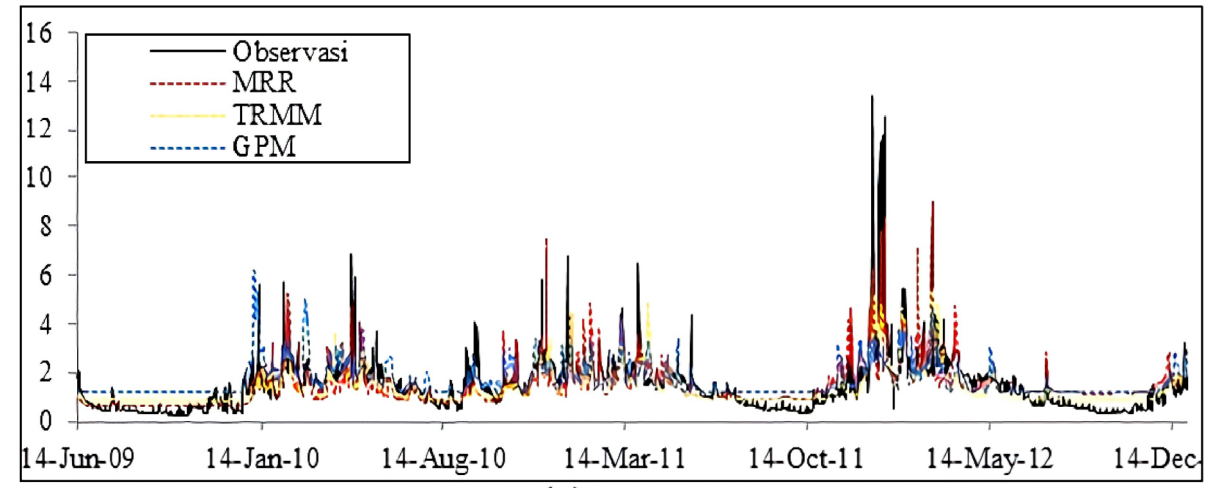

(c)

Figure 6. Comparison graph of observed discharge calibration with simulated discharge using 3 rainfall data products for the watershed: (A) Sampean Baru, (B) Bedadung, (C) Mayang 


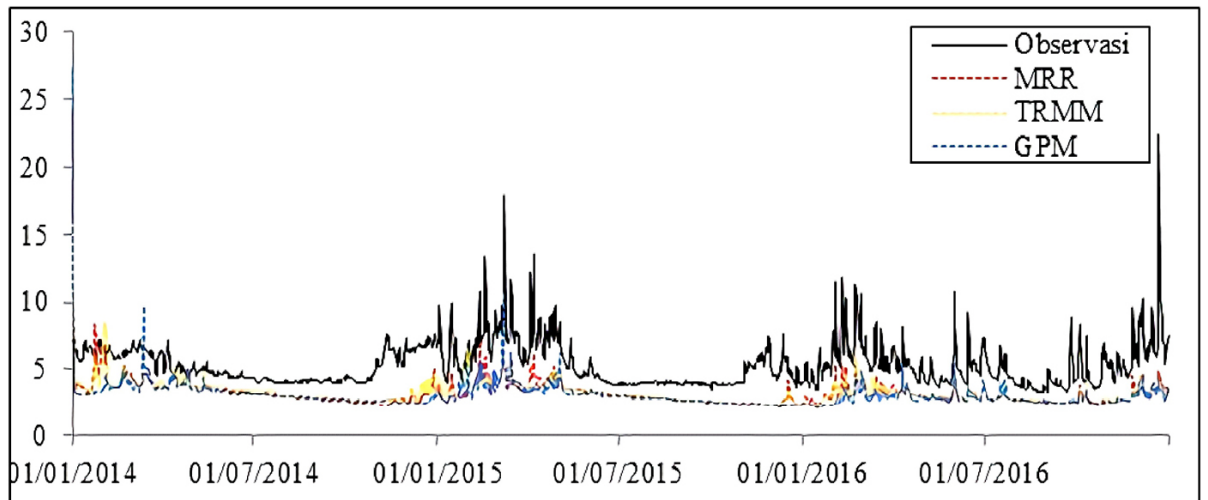

(a)

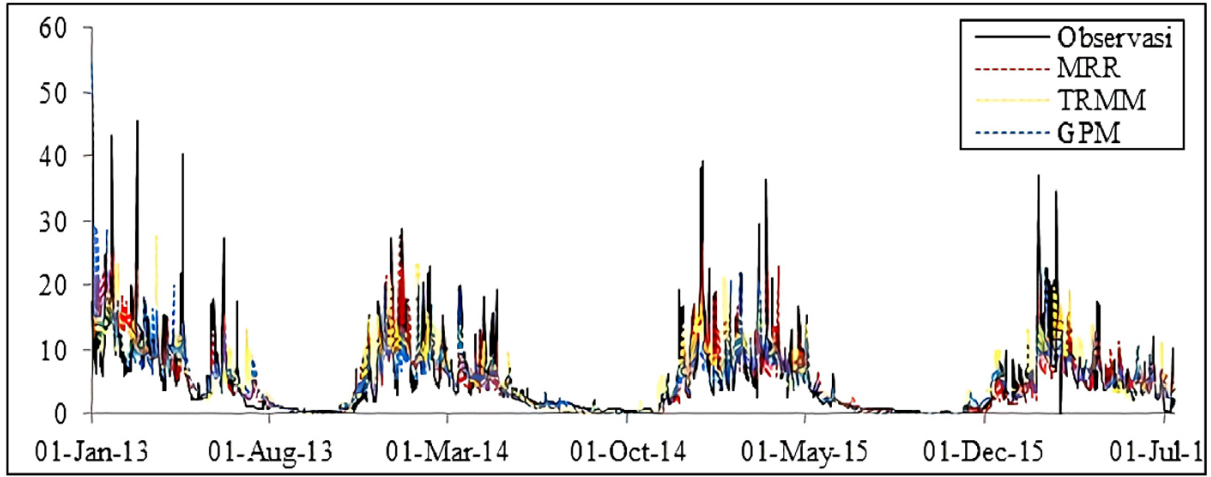

(b)

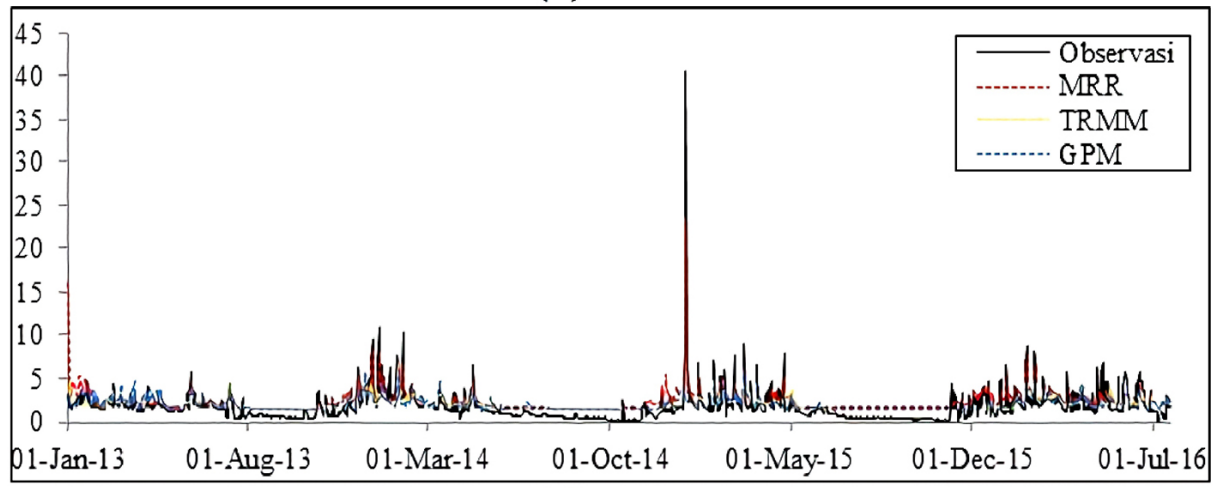

(c)

Figure 7. Comparison graph of observation discharge validation with simulated discharge using 3 rainfall data products for the watershed: (A) Sampean Baru, (B) Bedadung, (C) Mayang

watershed with a data period of 3 years for calibration (2011-2013), the trend of model simulation with MMR input almost follows the observed discharge pattern compared to the trend of TRMM-3B42 and GPM-3IMERGDF which tend to under-estimate and over-estimate. The Bedadung and Mayang watersheds for the 5-year calibration data period (2008-2017) have a simulation trend that is almost similar to the observations for MMR products. The simulation of the Bedadung and Mayang watersheds for the TRMM-3B42 and GPM-3IMERGDF satellite products is also almost the same as the observed discharge, but tends to have an over-estimated trend for the Mayang watershed and under-estimated for Bedadung.

Figure 8 , is a cumulative check between the observed discharge and the simulation results from 3 rainfall products. The accumulation of the simulated discharge of the three watersheds in the calibration and validation periods has a line gradient similar to the observed discharge.

\section{DISCUSSION}

Based on the results of the analysis, the MMR rainfall data product shows the higher the mean 


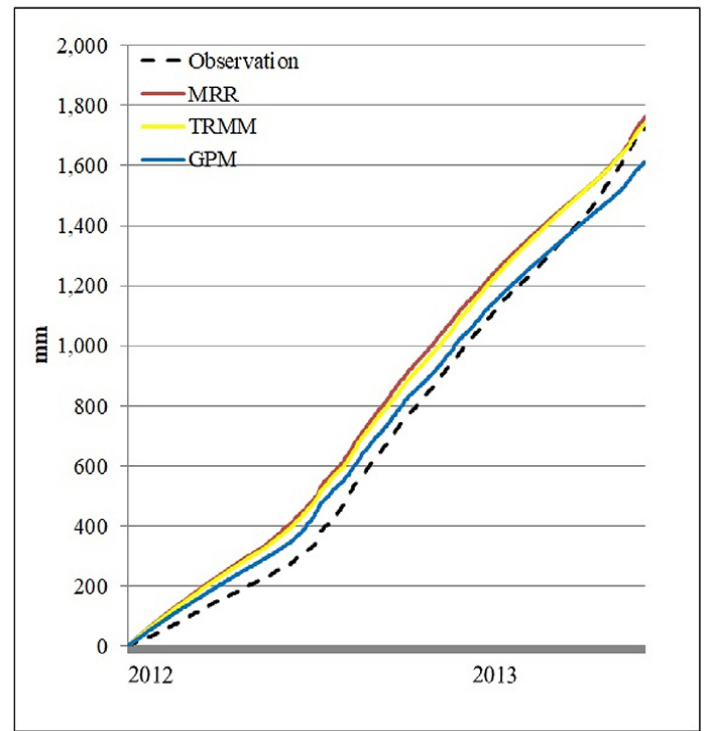

(a)

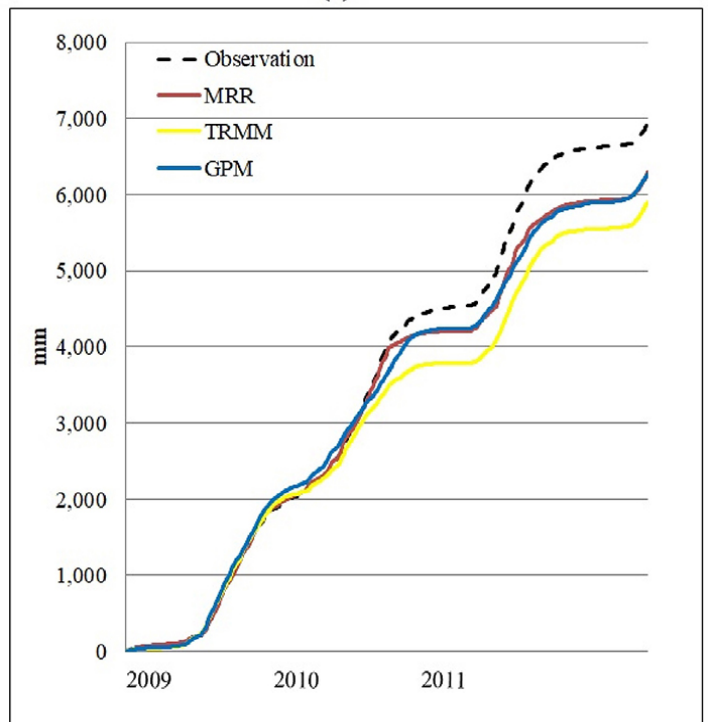

(c)

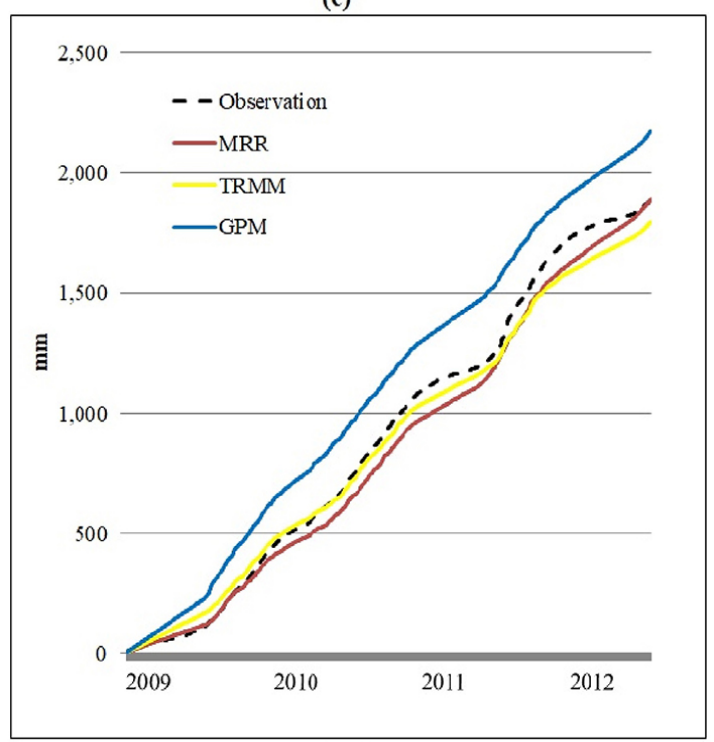

(e)

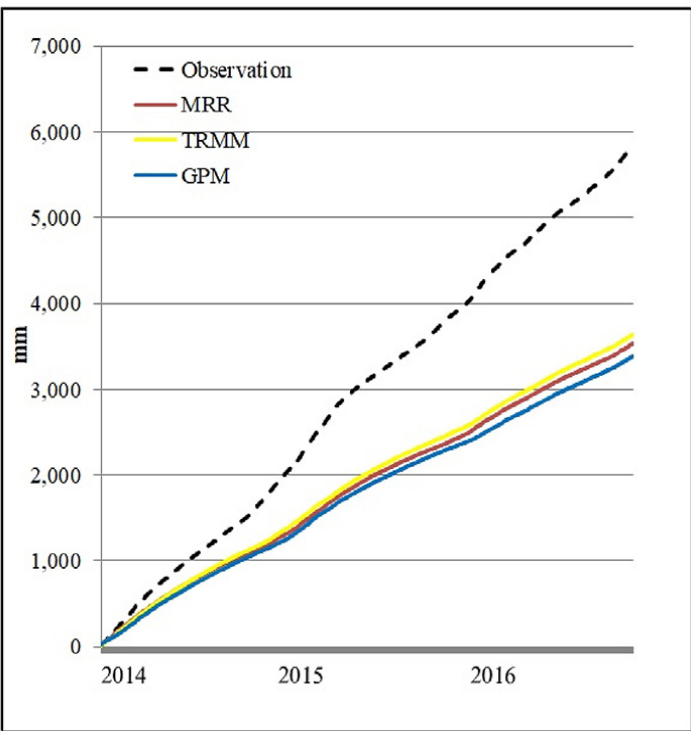

(b)

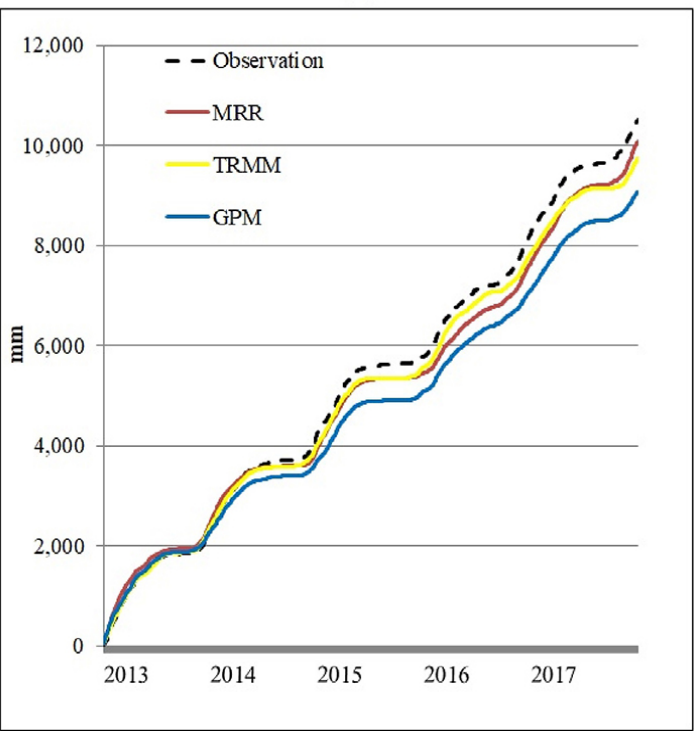

(d)

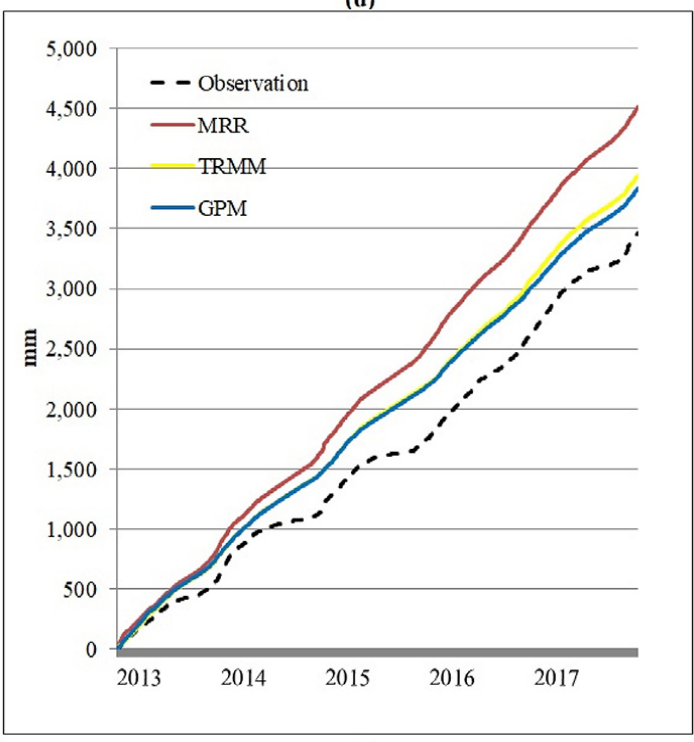

(f)

Figure 8. Cumulative annual discharge of calibration and validation period, sampean baru (A, B); Bedadung (C, D); Mayang (E, F) 
rain data, the higher the resulting standard deviation. In this case, the Sampean Baru watershed has the lowest mean area rainfall data compared to the other 2 watersheds, and the Sampean Baru watershed has the lowest standard deviation. So it shows that the quality ofthe MMR data in the Sampean Baru watershed is the best. This is the same as what was done by Pomeon et al, (2017) in the northernmost Lawra basin which has a low average rainfall with a low standard deviation so that it can affect the model in terms of good model performance. Meanwhile, the results of the mean rainfall data and the standard deviation of the satellite rainfall products for each watershed in Figure 3 show that the mean rainfall data for GPM3IMERGDF is higher than TRMM-3B42 with an increase in the mean rainfall of $7.1 \%$, on the contrary the standard deviation of GPM-IMERGDF was smaller than TRMM-3B42 with a decrease of $7.7 \%$. This shows that increasing the resolution from TRMM-3B42 to GPM-3IMERGDF results in better data quality that reduce the deviation as did Amorim et al.,(2020); Gilewski \& Nawalany, (2018); Zhang et al., (2019) which states that the GPM-3IMERGDF show a better match than the TRMM-3B42.

The results of the analysis between the mean and standard deviation associated with the correlation between the rainfall data showed that the new sample produced the best correlation compared to the other two watersheds. This shows that a small standard deviation will produce a good correlation. Based on the Pbias values of TRMM-3B42 and GPM-3IMERGDF, it shows that the satellite product is inconsistent with MMR where the values are over-estimated (TRMM-3B42 and GPM-3IMERGDF in the Sampean Baru watershed and GPM-3IMERGDF in Bedadung watershed) and under-estimated. The results of stationarity analysis of rainfall data for all watersheds show that all rainfall products have seasonal differences during the observed data period so that they can be used for hydrological modeling processes. However, from the stationarity analysis of the discharge data, there is one watershed that is not stationary, namely the Sampean Baru watershed.

After modeling the rainfall data, the results show that the MMR product gives satisfactory results compared to the other 2 satellite products. Next, GPM-3IMERGDF gives slightly better results than TRMM-3B42 with a 3\% increase in NSE value. This is in-line with the increase in the correlation value of satellite rainfall data to MMR by $5 \%$. Satisfactory model performance, both for satellite and MMR products, can be seen in the calibration and validation results in the Bedadung watershed. This is supported by the quality of the rainfall data and stationary discharge data, which gives results in accordance with the model's performance. Furthermore, in the second watershed, Sampean Baru has less than satisfactory performance for both satellite products and satisfactory for MMR field rainfall measurements. The Mayang watershed has an unsatisfactory performance both for satellite products and for measuring rainfall in the field. In general, the performance of the HBV Light model based on the NSE values in the three watersheds with MMR rainfall data as input is acceptable. The parameters obtained from the calibration vary in each watershed and all the parameters are interconnected to get a good model response. Guse et al, (2020) look for value parameters to produce a good performance model. In order to identify the value-appropriate parameter model, usually, a large number of simulation models with different combinations of parameters are carried out and based on performance criteria.

Evaluation of the model results contained in Figure 7 during the validation period found that the Sampean Baru watershed had a negative NSE value that unsatisfactory performance among the other two watersheds. This performance can be seen from the trend of the simulation results of the three products in the Sampean Baru watershed unable to follow the observed discharge trend pattern. However, there is a similar trend pattern in the simulation using the MMR field measurement product with the other two satellite products. Reinforced by Figure 8, which is a cumulative check between the observed discharge and the simulation results of 3 rainfall products. The accumulated discharge of the three watershed simulations in the calibration and validation periods has a line gradient similar to the observed discharge. However, there are quite large gradient differences in the validation period in the Sampean Baru watershed. This gradient difference is possible because the discharge data is not stationary. This indicates that the input data for that period and that catchment are problematic and there is a need for ground base measurements to correct the satellite estimates. 


\section{CONCLUSIONS}

The evaluation of the performance of this model is carried out thoroughly both on the rainfall data product and the performance of the model with a variety of appropriate statistical tests. The correlation of areal rainfall data between MMR and satellite products has a moderate to good correlation in the Sampean Baru, Bedadung, and Mayang watersheds, which are 703 $\mathrm{km}^{2}, 648 \mathrm{~km}^{2}, 578 \mathrm{~km}^{2}$, respectively. In addition, the ADF test shows all rainfall data products in all stationary watersheds to the average. While the ADF test on the discharge data is only the Sampean Baru watershed which is not stationary with respect to the average.

In general, the HBV Light model with various inputs of rain data products provides the same model simulation pattern as the observed discharge. This model is good at representing low to moderate discharge in the three watersheds but is not yet able to represent peak discharge. Satellite rainfall data product from GPM-3IMERGDF slightly better than TRMM-3B42 as HBV Light model. The results of the one-way ANOVA test show that all parameters affect the response of the model simultaneously. The performance of HBV Light modeling in the calibration process is still acceptable for all watershed areas from the best, respectively, to Bedadung Watershed, Sampean Baru Watershed, and Mayang Watershed. The small NSE value in the Mayang watershed is reinforced by the results of the Tukey multiple tests, the Mayang watershed has the largest FC average value compared to the other two watersheds. While the performance of the model in the validation process is not in line with the calibration process, because the discharge data of the Sampean Baru watershed which is not stationary on average has a negative effect on the NSE value.

In this study, the conceptual hydrological model of HBV Light proved to be easy to learn to give good results. In addition, various statistical tests can explain the weaknesses of the model's performance. The challenge to get better performance of the HBV Light model is to increase the correlation between satellite rainfall and MMR rain, by first modeling the satellite rainfall data product or looking for another more suitable satellite rainfall product.

\section{REFERENCES}

1. Abebe N.A., Ogden F.L., Pradhan N.R. 2010. Sensitivity and uncertainty analysis of the conceptual HBV rainfall-runoff model: Implications for parameter estimation. Journal of Hydrology, 389(3-4), 301-310. https://doi.org/10.1016/j. jhydrol.2010.06.007

2. Alazzy A.A., Lü H., Chen R., Ali A.B., Zhu Y., Su J. 2017. Evaluation of Satellite Precipitation Products and Their Potential Influence on Hydrological Modeling over the Ganzi River Basin of the Tibetan Plateau. Advances in Meteorology, 2017. https:// doi.org/10.1155/2017/3695285

3. Alhamda M.Z., Hidayah E., Yunarni W. 2020. Perbandingan Estimasi Curah Hujan Mrr Dan Trmm B342 Sebagai Input Model Hidrologi Hbv Studi Kasus Das Bedadung. Rekayasa Sipil, 14(2), 112-119. https://rekayasasipil.ub.ac.id/index.php/rs/article/ view/676/468

4. Amorim J. da S., Viola M.R., Junqueira R., de Oliveira V.A., de Mello C.R. 2020. Evaluation of satellite precipitation products for hydrological modeling in the brazilian cerrado biome. Water (Switzerland), 12(9). https://doi.org/10.3390/W12092571

5. Azka M.A., Sugianto P.A., Silitonga A.K., Nugraheni I.R. 2018. Uji Akurasi Produk Estimasi Curah Hujan Satelit Gpm Imerg Di Surabaya, Indonesia. Jurnal Sains \& Teknologi Modifikasi Cuaca, 19(2), 83. https://doi.org/10.29122/jstmc.v19i2.3153

6. Behrangi A., Khakbaz B., Jaw T.C., AghaKouchak A., Hsu K., Sorooshian S. 2011. Hydrologic evaluation of satellite precipitation products over a midsize basin. Journal of Hydrology, 397(3-4), 225237. https://doi.org/10.1016/j.jhydrol.2010.11.043

7. Bergström S. 1976. Development and Application of a Conceptual Runoff Model for Scandinavian Catchments. Smhi, RHO 7(November), 134.

8. Bergström S. 1992. The HBV model - its structure and applications. Swedish Meteorological and Hydrological Institute, Norrköping, 4(4), 1-33.

9. Bitew M.M., Gebremichael M. 2011. Assessment of satellite rainfall products for streamflow simulation in medium watersheds of the Ethiopian highlands. Hydrology and Earth System Sciences, 15(4), 11471155. https://doi.org/10.5194/hess-15-1147-2011

10. Booij M.J. 2003. Determination and integration of appropriate spatial scales for river basin modelling. Hydrological Processes, 17(13), 2581-2598. https:// doi.org/10.1002/hyp.1268

11. Braun J.N., Renner C.B. 1990. Application of a conceptual runoff model in different physiographic regions of Switzerland. Hydrological Sciences Journal, 37(3), 217-231. https://doi. org/10.1080/02626669209492583 
12. Cryer J.D., Chan K.-S. 2008. Time series analysis With Applications in R. Springer US.

13. Moriasi D.N., Arnold J.G., Van Liew M.W., Bingner R.L., Harmel R.D., Veith T.L. 2007. Model Evaluation Guidelines for Systematic Quantification of Accuracy in Watershed Simulations. Transactions of the ASABE, 50(3), 885-900. https://doi. org/10.13031/2013.23153

14. Fujihara Y., Yamamoto Y., Tsujimoto Y., Sakagami J.-I. 2014. Discharge Simulation in a Data-Scarce Basin Using Reanalysis and Global Precipitation Data: A Case Study of the White Volta Basin. Journal of Water Resource and Protection, 6(14), 13161325. https://doi.org/10.4236/jwarp.2014.614121

15. Gilewski P., Nawalany M. 2018. Inter-comparison of Rain-Gauge, Radar, and Satellite (IMERG GPM) precipitation estimates performance for rainfallrunoff modeling in a mountainous catchment in Poland. Water (Switzerland), 10(11), 1-23. https:// doi.org/10.3390/w10111665

16. Gu H., Yu Z., Yang C., Ju Q. 2010. Hydrological assessment of TRMM rainfall data over Yangtze River Basin. Water Science and Engineering, 3(4), 418-430. https://doi.org/10.3882/j. issn.1674-2370.2010.04.005

17. Gupta H.V., Sorooshian S., Yapo P.O. 1999. Status of Automatic Calibration for Hydrologic Models: Comparison with Multilevel Expert Calibration. Journal of Hydrologic Engineering, 4(2), 135-143. https:// doi.org/10.1061/(asce)1084-0699(1999)4:2(135)

18. Guse B., Kiesel J., Pfannerstill M., Fohrer N. 2020. Assessing parameter identifiability for multiple performance criteria to constrain model parameters. Hydrol. Sci. J., 65(7), 1158-1172. https://doi.org/ 10.1080/02626667.2020.1734204.

19. Hidayati F., Hidayah E., Halik G. 2020. Prediksi Curah Hujan Dengan Pemodelan Jaringan Syaraf Tiruan Di Das Mayang Kabupaten Jembers. Pertemuan Ilmiah Tahunan HATHI Ke-37, Nov., 1-12

20. Huang Y., Bárdossy A., Zhang K. 2018. Sensitivity of hydrological model to the temporal and spatial resolutions of rainfall input. Hydrology and Earth System Sciences Discussions, 2008, 1-34. https:// doi.org/10.5194/hess-2018-469

21. Huffman G.J., Adler R.F., Bolvin D.T., Gu G., Nelkin E.J., Bowman K.P., Hong Y., Stocker E.F., Wolff D.B. 2007. The TRMM Multisatellite Precipitation Analysis (TMPA): Quasi-global, multiyear, combined-sensor precipitation estimates at fine scales. Journal of Hydrometeorology, 8(1), 38-55. https:// doi.org/10.1175/JHM560.1

22. Indarto, Wahyuningsih S., Pudjojono M., Ahmad H., Ahmad Y. 2014. Studi Pendahuluan tentang Penerapan Metode Ambang Bertingkat untuk Analisis Kekeringan Hidrologi pada 15 DAS di Wilayah Jawa Timur. Jurnal Agroteknologi, 8(2), 112-121.
23. Khalili K., Ahmadi F., Dinpashoh Y., Fard A.F. 2013. Determination of Climate Changes on Streamflow Process in the West of Lake Urmia with Used to Trend and Stationarity Analysis. International Journal of Advanced Biological and Biomedical Research, 1(10), 1220-1235. http://www.ijabbr.com

24. Koutsouris A.J., Chen D., Lyon S.W. 2016. Comparing global precipitation data sets in eastern Africa: A case study of Kilombero Valley, Tanzania. International Journal of Climatology, 36(4), 2000-2014. https://doi.org/10.1002/joc.4476

25. Lakew H.B., Moges S.A., Asfaw D.H. 2020. Hydrological performance evaluation of multiple satellite precipitation products in the upper Blue Nile basin, Ethiopia. Journal of Hydrology: Regional Studies, 27(August 2018), 100664. https://doi.org/10.1016/j. ejrh.2020.100664

26. Linde A.T.E., Hurkmans R., Aerts J. 2007. Comparing model performance of the HBV and VIC models in the Rhine basin. July, 278-285.

27. Lindström G., Johansson B., Persson M., Gardelin M., Bergström S. 1997. Development and test of the distributed HBV-96 hydrological model. Journal of Hydrology, 201(1-4), 272-288. https://doi. org/10.1016/S0022-1694(97)00041-3

28. Liu Z. 2014. Comparison of precipitation estimates between Version 7 3-hourly TRMM Multi-Satellite Precipitation Analysis (TMPA) near-real-time and research products. Atmospheric Research, 153(October), 119-133. https://doi.org/10.1016/j. atmosres.2014.07.032

29. Mamenun M., Pawitan H., Sopaheluwakan A. 2014. Validasi Dan Koreksi Data Satelit Trmm Pada Tiga Pola Hujan Di Indonesia. Jurnal Meteorologi Dan Geofisika, 15(1). https://doi.org/10.31172/jmg.v15i1.169

30. Mendez M., Calvo-Valverde L. 2016. Development of the HBV-TEC Hydrological Model. Procedia Engineering, 154, 1116-1123. https://doi.org/10.1016/j. proeng.2016.07.521

31. Nash J.E., Sutcliffe J.V. 1970. River Flow Forecasting Through Conceptual Model Part I - A Discussion of Principles.

32. Osuch M., Romanowicz R.J., Booij M.J. 2015. Influence de l'incertitude paramétrique sur les relations entre les paramètres du modèle par le VHB et les caractéristiques climatiques. Hydrological Sciences Journal, 60(7-8), 1299-1316. https://doi.org /10.1080/02626667.2014.967694

33. Poméon T., Jackisch D., Diekkrüger B. 2017. Evaluating the performance of remotely sensed and reanalysed precipitation data over West Africa using HBV light. Journal of Hydrology, 547, 222-235. https:// doi.org/10.1016/j.jhydrol.2017.01.055

34. Rusli S.R., Yudianto D., Liu J. 2015. Effects of temporal variability on HBV model calibration. Water 
Science and Engineering, 8(4), 291-300. https://doi. org/10.1016/j.wse.2015.12.002

35. Rutkowska A., Ptak M. 2012. On Certain Stationarity Tests for Hydrologic Series. Studia Geotechnica et Mechanica, 34(1), 51-63. https://doi.org/10.1515/ sgem-2017-0022

36. Said S.E., Dickey D.A. 1984. Testing for unit roots in autoregressive-moving average models of unknown order. Biometrika, 71(3), 599-607. https:// doi.org/10.1093/biomet/71.3.599

37. Seibert J. 2005. HBV light. HBV Light Version 2 User's Manual, November.

38. Seibert J., Vis M.J.P. 2012. Teaching hydrological modeling with a user-friendly catchment-runoffmodel software package. Hydrology and Earth System Sciences, 16(9), 3315-3325. https://doi. org/10.5194/hess-16-3315-2012

39. Tajudin N., Ya'acob N., Ali D.M., Adnan N.A. 2020. Estimation of TRMM rainfall for landslide occurrences based on rainfall threshold analysis. International Journal of Electrical and Computer Engineering, 10(3), 3208-3215. https://doi.org/10.11591/ ijece.v10i3.pp3208-3215

40. Thiemig V., Rojas R., Zambrano-Bigiarini M., De Roo A. 2013. Hydrological evaluation of satellitebased rainfall estimates over the Volta and BaroAkobo Basin. Journal of Hydrology, 499, 324-338. https://doi.org/10.1016/j.jhydrol.2013.07.012

41. Wang J., Wang H.J., Hong Y. 2016. Comparison of satellite-estimated and model-forecasted rainfall data during a deadly debris-flow event in Zhouqu, Northwest China. Atmospheric and Oceanic Science Letters, 9(2), 139-145. https://doi.org/10.1080/1674 2834.2016.1142825

42. Wei W.W.S. 2006. Time Series Analysis: Univariate and Multivariate Methods. In Technometrics, 33(1). https://doi.org/10.1080/00401706.1991.1 0484777

43. Worqlul A.W., Collick A.S., Tilahun S.A., Langan S., Rientjes T.H.M. 2015. Comparing TRMM 3B42, CFSR and ground-based rainfall estimates as input for hydrological models, in data scarce regions: the Upper Blue Nile Basin, 2081-2112. https://doi. org/10.5194/hessd-12-2081-2015

44. Xuan W., Fu Q., Qin G., Zhu C., Pan S., Xu Y.P. 2018. Hydrological simulation and runoff component analysis over a cold mountainous River Basin in Southwest China. Water (Switzerland), 10(11). https://doi.org/10.3390/w10111705

45. Zhang Z., Tian J., Huang Y., Chen X., Chen S., Duan Z. 2019. Hydrologic evaluation of TRMM and GPM IMERG satellite-based precipitation in a humid basin of China. Remote Sensing, 11(4), 1-20. https:// doi.org/10.3390/rs11040431

46. Zhao Y., Xie Q., Lu Y., Hu B. 2017. Hydrologic Evaluation of TRMM Multisatellite Precipitation Analysis for Nanliu River Basin in Humid Southwestern China. Scientific Reports, 7(1), 1-10. https://doi.org/10.1038/s41598-017-02704-1 